\title{
SPATIAL ENTROPY. A SMALL TOWN PERSPECTIVE. CASE STUDY: THE TOWN OF MARGHITA
}

\author{
Valentin NEMEŞ, Rodica PETREA, Mălina FILIMON \\ University of Oradea, Romania
}

\begin{abstract}
The concept of "spatial entropy" developed by Michael Batty (1974) was primarily used to test different hypotheses concerning the distribution and density of population in great cities like New York, London, Los Angeles. Subsequently spatial entropy was adapted in urban and regional studies, where two types of research have been outlined: - "descriptive statistics" and "MaxEnt" method (Esmer 2005). Three characteristic elements related to the three components of sustainable development (society, economy and environment) have been considered to shape the degree of entropy for the urban system Marghita, namely: population, turnover and green spaces. The determination of the entropy degree for the Marghita urban system was achieved by applying statistical physics functions on open systems, related to the three pillars of sustainable development. The three domains are represented by a series of dynamic and complex elements characterized by input and output streams, influenced by endogenous factors characteristics of urban system and exogenous factors from the higher integrator urban system.
\end{abstract}

Key Words: spatial entropy, urban system, sustainable development, small town Marghita.

\section{Introduction}

Society builds a different order from the natural one, by manipulating space in order to generate distinct ordered structures. Urban society converts natural space, whose behaviour is difficult to perceive in a more comprehensive space with known relationships that generate a space of certainty, in order to facilitate activities that define society, in other words, to domesticate the nature. This process is applicable to any anthropogenic development, but especially in urban areas where it is more obvious the over positioning of structural order. The society attempts to obtain a progressive optimization of its own activity, generating a rational accumulation of surpluses in terms of space resulting from the exploitation of nature, which is initially more organized. These surpluses are accumulated as structures with stability features (construction) that in principle are inseparable from the simultaneous creation of a property system (streets, parcels) and functions. Thus, a specific relationship is established between a production area and the accumulation space in terms of matter and energy (Tojo 2002).

Since the 1950s, when the General Systems Theory and Cybernetics began to be applied in social sciences, cities began to be treated formally as systems. The idea of a general system theory emerged from reflections on how distinct entities, formed by inferior elements, are organized into a coherent superior entity, in patterns and order. This was followed by a focus on how the elements interact with each other through structures that make the systems more 
sustainable within their limits. Cities fit into this characterization of systems as structures that require physical and aesthetic organization. Spatial analysis appeared in the science of geography, in relation with regional science, based on a urban and regional economy synthesis.

Cities were defined as sets of components connected by sets of interactions. Archetypal structure was designed around functional activities, and the connections between them were represented by physical movement, such as traffic. Since early applications of the general systems theory, the paradigm has been changed fundamentally from a world where systems were viewed as being centrally organized, from the top down, and notions about hierarchy were predominant, to one where we now consider systems to be structured from the bottom up (Batty 2008). This change in approach has brought under discussion notions of equilibrium and dynamics (lanoş 1994, lanoş 2000); cities as systems are no longer seen as structures in equilibrium, although models based on equilibrium are still useful in systems modelling. Urban systems are rather in imbalance all the time, a phenomenon observed in the velocity of changes and cities volatility. Changes are discontinuous, often chaotic, changes in the structure and behaviour of people are often difficult to predict, sometimes even surprising. Urban morphologies grow organically from bottom to top, even in planned cities which rarely keep their shape over long periods of time. Elements that compose urban structures are known as actors or agents, bound together by interactions that determine behavioural processes which keep the system in equilibrium or move it to new stages. The relationships between the system elements in terms of their interactions are enriched with ideas about networks and their dynamics. Key notions about how the elements of the systems are relatively scaled to each other and to the hierarchical system, demonstrate how local actions and interactions lead to global patterns that can be expected only from bottom to top, and these patterns can be generated using bottom-top growth models.

Landsberg's definition of order and disorder in 1990 explains the apparently abnormal phenomenon, that the entropy and disorder increase simultaneously. There must be a way of maintaining, or even increasing order, or decreasing disorder even by increasing the entropy: by maximising the total possible entropy to increase in a greater rhythm than the existing one. To achieve this, it is enough to increase the area in which the phenomenon occurs. In urban terms, the order can be maintained even if entropy increases, by extending the urban surface. Cities expanding is the economical form to decrease disorder with minimal energy cost. Until the advent of the automobile, the city expansion was controlled, but the possibility offered by the car through easiest travel at distance, increased the expansion phenomenon in cities, as the territory is being more accessible. There was an significant increase of the maximum possible entropy, which has led to the illusion that maintaining order is ensured, but the question arises on where will this expansion lead and what effect it will have on the natural environment.

\section{Methods and Data}

In urban and regional analysis studies, two types of research were defined using the concept of entropy. The first type uses "descriptive statistics" and the second type uses "Maxent" method (Esmer 2005). This method was applied to determine the pattern of urban sprawl (Kumar et al. 2007, Lata et al. 2001, Li \& Yeh 2004, Sudhira et al. 2004, Yeh \& Li 2001, Narisra et al. 2007, Guangjin et al. 2002).

Entropic analysis as shown below was firstly defined in this way by Shannon (1948) trying to explore the mechanism of information transmission in a noisy environment, but in reality, the 
formula is centred on the principles of statistical physics developed by Clausius in the 19th century, considering statistical interpretations made by Boltzmann and Gibbs related to thermodynamic entropy. The method of maximum entropisation associated with the identification of particle distribution in a physical context gives birth to the Boltzmann-Gibbs distribution as a reference point in analyzing the spatial distribution of components (Wilson 2008).

Entropy index has a degree of stability and uniformity in a system that changes from zero (maximum concentration) to one (maximum separation) (equation 1 and 2).

$$
\begin{aligned}
& H=\sum_{i=1}^{n} P_{i} \log \frac{1}{P_{i}}=\sum-P_{i} \log P_{i} \\
& R=1-\frac{H}{H_{\text {max }}}=\frac{H}{\log K} \quad \text { (Eq. 2), }
\end{aligned}
$$

Where $\mathrm{H}$ is the absolute entropy, $\mathrm{P}_{\mathrm{i}}$ shows the proportion of component analysis, $\mathrm{R}$ denotes the relative entropy, $\mathrm{H}_{\max }$ shows the maximum entropy (complete homogeneous distribution). If the component is concentrated in the studied region, then $R=0$, and if it is homogeneously distributed, then $\mathrm{R}=1$.

It stands out more attractive properties of this function to describe the spatial distribution. If $\mathrm{p}_{\mathrm{i}}=$ 1 and $\mathrm{pk}=0, \forall \neq \mathrm{i}$ and the entropy is minimal when $\mathrm{Hmax}=0$ if component is considered uniformly distributed $\mathrm{p}_{\mathrm{i}}=1 / \mathrm{n}, \forall \mathrm{i}$, then the entropy is maximum if $\mathrm{Hmax}=\operatorname{logn}$. Many distributions lie between these extremes and allow the construction of a series of related measures analyzed in terms of maximum entropy.

$$
\begin{aligned}
I & =H_{\max }-H=\log n+\sum_{i} p_{i} \log p_{i} \\
& =\sum_{i} p_{i} \log \frac{p_{i}}{1 / n}=\sum_{i} p_{i} \log \frac{p_{i}}{q_{i}}
\end{aligned}
$$

This equation is widely used in the probability theory, popularized by Kullback (1959), and discussed extensively in a geographic context (Snickers and Weibull 1977, Webber 1979). A normalization of $I$ as $R_{\max }=I / H$ is called the relative redundancy and it is a measure ranging between 0 and 1 .

For entropic analysis carried out over the city of Marghita, data used were collected both from statistical sources (National Census), local statistical records (Fișa Localității) and planning documents such as County Development Plan, Integrated Urban Development Plan and Marghita Land Use Plan. These data were processed in order to be included in the entropy formula. Batty's method applied in the present study reflects a status parameter for Marghita. Complementary, a synthetic method was used for argumentative reasons to highlight the state of key factors which are representative for the studied area.

Small towns have special dynamics. Most relevant indicators to determine the status they had both in the local development and regional development are about the demographics, 
economics and about the environmental quality.

\section{Results and Discussion}

Spatial entropy through Batty's method in a synthesized form was applied to the city of Marghita. The city is located in the north-eastern part of Bihor County (Nemeş, 2010), near the river Barcau (Petrea, 1998) and in the proximity of the Transylvania Motorway. The entropy analysis of the Marghita urban system was achieved by applying statistical physics functions on open systems, related to the three pillars of sustainable development (social, economic and environment). The three domains are represented by a series of dynamic and complex elements characterized by input and output streams influenced by endogenous factors characteristics of urban systems and exogenous factors from the higher urban integrator system.

Three characteristic elements from three components of sustainable development have been considered in shaping the entropy degree of the Marghita urban system, namely:

- Population - characterized by structural complexity and continuous dynamics represented by inflows (birth, immigration) and outflows (mortality, migration), primordial element of urban system generating relationships with the other components, influencing them directly through the multitude of activities;

Marghita is the main polarizing centre of the region being attractive to adjacent rural areas, due to its urban comfort that it can provide and because of the opportunity given to find a job. In fact, statistical data provided by the authorities show that between 2006 and 2007, the number of persons settling in the city of Marghita increased 7.5 times, being recorded 1101 requests for establishing the domicile in the town. Marghita is a town with a natural and migratory positive balance maintaining their population over 15,000 inhabitants.

- Turnover - is the catalyst of the urban system, produced under direct action of human component, favoured by local resources. Determined by endogenous factors (economic units, production...) and exogenous (investment, financial support).

Marghita has built a stable economy combining industrial or agricultural activities, trade and transport, being an important economic and socio-cultural centre, ranked as a second economic power in Bihor county, after the county seat, respectively, the municipality of Oradea (PDJ, 2007). In 2009 in Marghita a total number of 804 economic units was registered (Lista firme, 2009).

Concerning the total turnover of local economic entities, its amount was $257,801,290$ lei (INS, 2009). From the chart below we can see that the fields with the highest level of financial capital running are the trade and industry sectors, accounting more than half of the total amount. The services, construction and transport area are close to the 30 million lei in terms of turnover. The transition to a mature economy is expected with an increase of the tertiary sector's importance (e.g. the services).

- Green areas - qualitative component perceived by the human being also under its pressure. It is the result of inputs determined by the expansion of green space and the output generated by the consumption of space triggered by urbanization. The quality of the green space in urban areas plays an important role in determining the quality of life but also increases its attractiveness. 


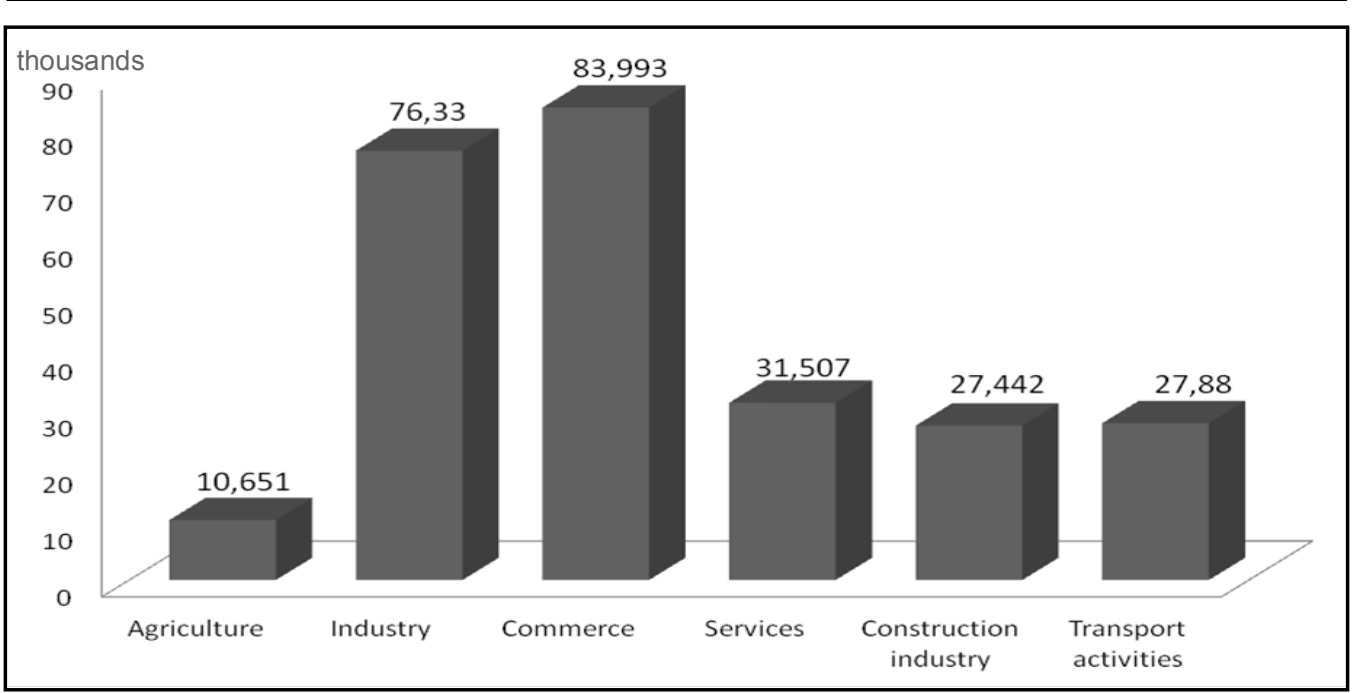

Fig. 1 - Distribution of Turnover by Activity Areas in Marghita

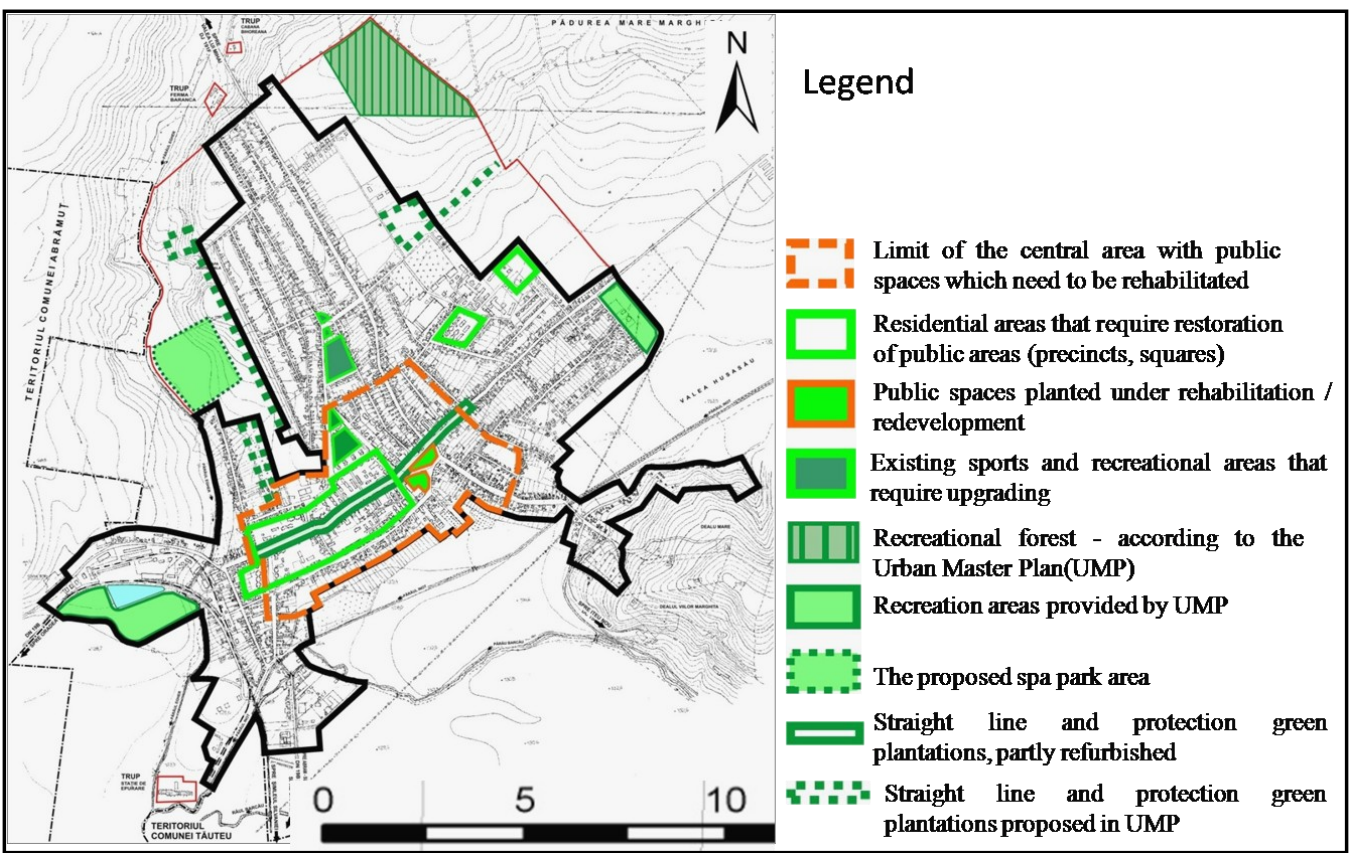

Fig. 2 - The State of Green Spaces in Urban Area of Marghita

Thus, applying Batty's developed function for the three analysed elements, the entropy degree is 0.938 taking into account the existing population in 2009. The turnover for 2009 in Marghita was 24.57 million Ron / capita, compared to 33.02 million Ron / capita for Bihor county, the entropy of the element considered is 0.969 . For analysis taking into account entropic green 
spaces the determined value was 0.828. For entropic analysis taking into account the environmental element represented by green spaces the determined value was 0.828 .

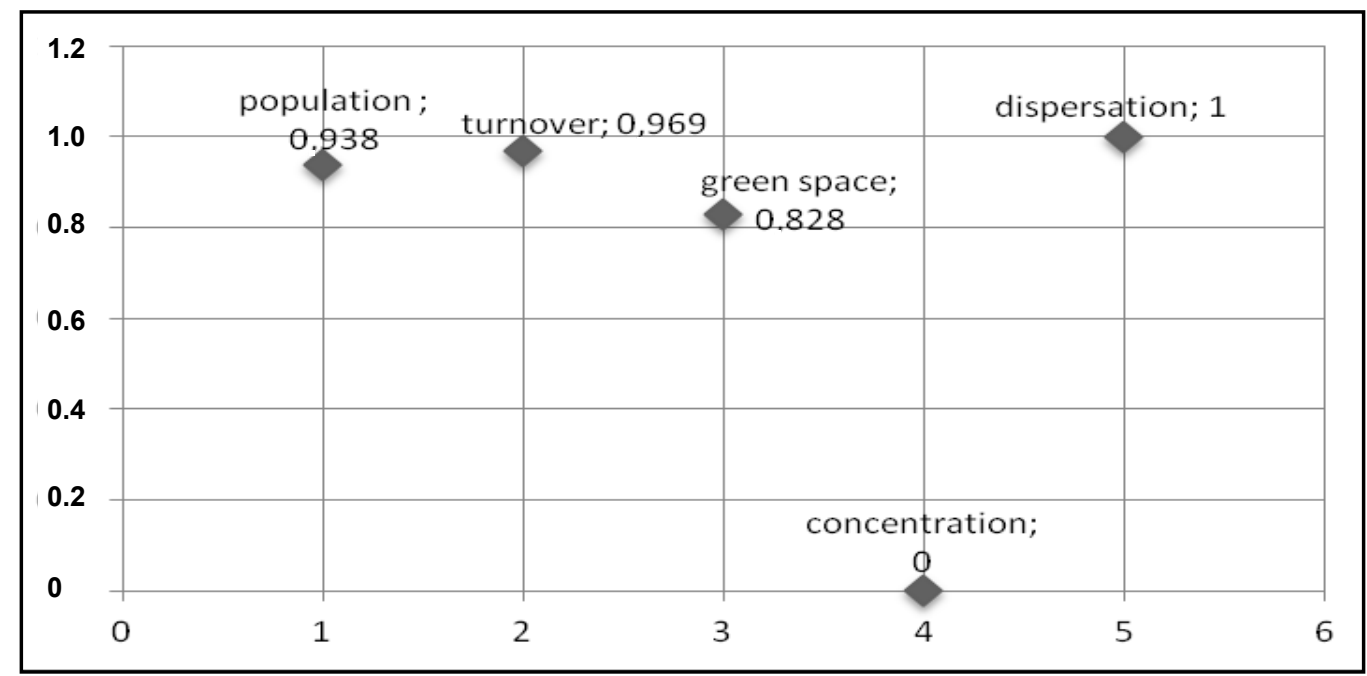

Fig. 3 - The Entropy Degree of the Three Analyzed Elements Data source: PIDU 2009, INS.TEMPO 2009, PUG 2009

The three analyzed elements show a high degree of low entropy for the urban system of Marghita analyzed through the integrator system of Bihor County. The two elements, population and turnover analyzed by Batty's equation reveal the presence of a latent, inhomogeneous space, which revolves around the Marghita urban system and a flow towards the Oradea urban system. The surface of landscaped green spaces in Bihor county, generally exists in urban centres rather than in rural areas, fact that causes relatively homogeneous distribution within administrative units but it is still dispersed in Bihor County.

Entropic analysis on urban entity requires a systemic approach aiming an assessment of the general entropy at the level of that entity as unitary system based on entropic reports at the subsystems components levels (social, economic, environmental and territorial).

If, in a very general perspective, the determination of system entropy could mean finding the disorganization index of that system, in terms of sustainable urban development, the determination of the entropy of Marghita represents a process of evaluating a state parameter that characterizes the urban system.

It starts from the vision of thermodynamics related to the entropic consumption of a system expressed in relations (R1, R2):

$$
F=U-T \text { * } S(R 1) ; \text { and } S=(U-F) / T(R 2) ;
$$

Where: $F$ - the free energy of the system;

$U$ - the internal energy of the system;

$\mathrm{T}$ - the absolute temperature of the system;

$S$ - the entropy;

Thus, an equivalent relation and applicable to any geographical and environmental elementary system is determined in the following form: 
$P i+P a=P u+P d(R 3)$ and $P d=(P i+P a)-P u(R 4)($ Lețos 2011);

Where:

$\mathrm{Pi}$ - Initial potential (inside) of a system;

$\mathrm{Pa}$ - Attracted potential from the external environment;

$\mathrm{Pu}$ - Consumed potential in a useful action;

$\mathrm{Pd}$ - Degraded potential which may have several components;

A complex of elements represented by material, energy and information mobilized to achieve a useful action is defined through the "potential concept".

\begin{tabular}{|c|c|c|c|c|c|c|c|c|}
\hline & $\mathbf{P}_{\mathbf{i}}$ & Arguments & $\mathbf{P}_{\mathbf{a}}$ & Arguments & $\mathbf{P}_{\mathrm{u}}$ & Arguments & $\mathbf{P}_{\mathrm{d}}$ & Arguments \\
\hline $\begin{array}{l}\text { E } \\
\text { c } \\
\text { o } \\
n \\
\text { o } \\
\text { m } \\
\text { y }\end{array}$ & $\mathrm{e}^{+}$ & $\begin{array}{l}\text { - commercial } \\
\text { tradition (from } \\
\text { oppidum to the } \\
\text { municipality); } \\
\text { - local natural } \\
\text { resources, }\end{array}$ & $\mathrm{e}^{+}$ & $\begin{array}{l}\text { - labour force } \\
\text { attraction; } \\
\text { - market for } \\
\text { certain } \\
\text { products }\end{array}$ & $\mathrm{e}^{+}$ & $\begin{array}{l}\text { - low unem- } \\
\text { ployment rate } \\
\text { compared to } \\
\text { national and } \\
\text { regional } \\
\text { averages; }\end{array}$ & $e^{-}$ & $\begin{array}{l}\text { - economic } \\
\text { restructuring; } \\
\text { - economic } \\
\text { crisis; } \\
\text { - scarce of } \\
\text { natural } \\
\text { resources }\end{array}$ \\
\hline $\begin{array}{l}\text { S } \\
\text { o } \\
\text { c } \\
\mathrm{i} \\
\text { a } \\
\text { I }\end{array}$ & $\mathrm{e}^{+}$ & $\begin{array}{l}\text { - homogene- } \\
\text { ous human } \\
\text { component; } \\
\text { - access to } \\
\text { utilities; } \\
\text { - low-poverty } \\
\text { rate; }\end{array}$ & $\mathrm{e}^{+}$ & $\begin{array}{l}\text { - pupils and } \\
\text { students } \\
\text { attracted by } \\
\text { the local } \\
\text { educational } \\
\text { institutions }\end{array}$ & $\mathrm{e}^{+}$ & $\begin{array}{l}\text { - high } \\
\text { percentage of } \\
\text { young peo- } \\
\text { ple, and } \\
\text { adults; }\end{array}$ & $\mathrm{e}^{-}$ & $\begin{array}{l}\text { - emphasis of } \\
\text { social } \\
\text { disparities; } \\
\text { - increase of } \\
\text { social } \\
\text { exclusion; }\end{array}$ \\
\hline $\begin{array}{l}\text { E } \\
\text { n } \\
\text { v } \\
\text { i } \\
\text { r } \\
\text { o } \\
\text { n } \\
\text { m } \\
\text { e } \\
\text { n } \\
\text { t }\end{array}$ & $\mathrm{e}^{+}$ & $\begin{array}{l}\text { - favourable } \\
\text { natural frame; } \\
\text { - accessibility }\end{array}$ & 0 & & $\mathrm{e}^{+}$ & $\begin{array}{l}\text { - renewable } \\
\text { resources }\end{array}$ & $\mathrm{e}^{-}$ & $\begin{array}{l}\text { - environ- } \\
\text { mental } \\
\text { pollution; }\end{array}$ \\
\hline $\begin{array}{l} \\
\text { e } \\
\text { r } \\
r \\
\mathbf{r} \\
\text { t } \\
0 \\
\text { r } \\
\text { y }\end{array}$ & $\mathrm{e}^{+}$ & $\begin{array}{l}\text { - coherent and } \\
\text { homogeneous } \\
\text { unit; }\end{array}$ & $\mathrm{e}^{+}$ & $\begin{array}{l}\text { - polarization } \\
\text { of the } \\
\text { countryside; }\end{array}$ & $\mathrm{e}^{+}$ & $\begin{array}{l}\text { - physical- } \\
\text { geographical } \\
\text { potential; }\end{array}$ & $e^{-}$ & $\begin{array}{l}\text { - transforma- } \\
\text { tion / degrada- } \\
\text { tion as a } \\
\text { result of } \\
\text { anthropic } \\
\text { activities }\end{array}$ \\
\hline
\end{tabular}

Entropic analysis at the level of each subsystem is based on a matrix of conceptual status according to the R3 formula, through which appreciation for the four types of specific potential 
of all components taken into account are formulated to estimate the entropic state of each component, and finally being estimated entropic state of the whole subsystem. In an intuitive form we can deduce the entropic state of Marghita urban system, that associates opposed entropic states searching an average value related to an imaginary axis of symmetry in the point 0 , as a potential equilibrium area, resulting in a moderately positive general entropy state.

In another way, by using mathematical calculation, the entropy state of the entire system results from the summing of all entropy states of the four subsystems, knowing that the positive entropy value $\left(\mathrm{e}^{+}\right)$at the systemic level is balanced or annulled from the mathematics perspective with a negative entropy value $\left(\mathrm{e}^{-}\right)$, the follow formula can be developed:

Where:

$$
\mathrm{e}^{+}(\mathrm{S} 1)+\mathrm{e}^{++}(\mathrm{S} 2)+\mathrm{e}^{-}(\mathrm{S} 3)+0(\mathrm{~S} 4)=\mathrm{e}^{+}(\mathrm{S}) ; \quad(\mathrm{R} 5)(\text { Lețos 2011) }
$$

$\mathrm{e}^{+}(-$positive entropy value;

$\mathrm{e}^{-}$- negative entropy value;

0 - null entropy value from mathematics point of view but balanced value at the system level;

$\mathrm{S} 1, \mathrm{~S} 2, \mathrm{~S} 3, \mathrm{~S} 4$ - are the four subsystems components: social, economic, environmental and territory;

S - urban entity system.

\begin{tabular}{|l|l|l|l|l|l|}
\hline $\begin{array}{l}\text { Entropic } \\
\text { state }\end{array}$ & $\begin{array}{l}\text { Major } \\
\text { negative }\end{array}$ & $\begin{array}{l}\text { Moderate } \\
\text { negative }\end{array}$ & Equilibrium & $\begin{array}{l}\text { Moderate } \\
\text { positive }\end{array}$ & Major positive \\
\hline $\begin{array}{l}\text { Entropic } \\
\text { value }\end{array}$ & $\mathrm{e}^{++}$ & $\mathrm{e}^{+}$ & 0 & $\mathrm{e}^{-}$ & $\mathrm{e}^{--}$ \\
\hline Marghita & & $\mathrm{x}$ & & & \\
\hline
\end{tabular}

The result revealed the presence of a moderate positive entropy state, which shows a moderate entropic disequilibrium in the sense of accumulation at the system level in a slow rhythm but continuous of used and uncompensated materials, energy and information through a consistent consumption of this accumulation and generation of negative entropy.

The environment subsystem is the only one with negative entropic potential that cannot compensate, only partially the accumulations of positive entropy at the level of social and economic subsystems, being able to establish the equilibrium only in ambivalent relations, to determine a supportable state with the social subsystem and a viable state with the economic subsystem, without the ability to intervene and compensate precarious condition resulting from interference between social and economic both in terms of equity and quality or performance and sustainability (Lețos 2011). The entropic analysis highlights the ability of small towns to maintain coherence across regions, indicating the status-quo of the dynamics, flows (disorder of analyzed elements). Generally applied to regions and cities, this method can be adapted to smaller units as in this case. This parameter status alongside other spatial analysis play an important role in territorial management.

\section{Conclusions}

Although Marghita is a small town, its systemic complexity in the entropic analysis presents some peculiarities caused by the relations of inputs and outputs flows in the urban system. Based on Batty's spatial entropy formula, the presence of an unused, inhomogeneous space stands out and revolves around the Marghita urban system and flows toward the Oradea urban 
system.

Positive entropy state generates a weak level of urban sustainability mainly caused by a complex social problem exacerbated by demographic factors and the economic crisis of recent years, in relation to a fragile economic subsystem, poorly consolidated, in a perpetual change and adaptation, still unable to perform, to resist the social pressure and to ensure a decent life for a large majority of the population.

This lack of sustainability is supplied by certain specific factors related to: poor human capital management, precarious management of urban space including green spaces, low use of renewable energy, lack of research and innovation activities, poor business opportunities, partial management of urban pollution, reduced emphasis on territorial cohesion.

\section{References}

BATTY, M. (1974), Spatial Entropy, Geographical Analysis, 6, pp. 1-31.

BATTY, M. (1976), Entropy in Spatial Aggregation, Geographical Analysis, 8, pp. 1-21.

BATTY, M., (2008), Cities as Complex Systems, Scaling, Interactions, Networks, Dynamics and Urban Morphologies, UCL WORKING PAPERS SERIES.

BOLTZMANN, L. (1974), The second law of thermodynamics. Populare Schriften, Essay 3, address to a formal meeting of the Imperial Academy of Science, 29 May 1886, reprinted in Ludwig.

ESMER, O. (2005), Information theory, entropy and urban spatial structure, Ph.D. Thesis, Department of city and regional planning, Middle East Technical University, Turkey.

GUANGJIN, T., JIYUAN, L., ZENGXIANG, Z. (2002), Urban functional structure characteristics and transformation in China, Cities, 19, 4, pp. 243-248.

IANOŞ, I., TĂLÂNGĂ, C. (1994), Oraşul şi sistemul urban românesc în condițiile economiei de piață, Inst. de Geografie, București.

IANOŞ, I. (2000), Sisteme teritoriale, Ed. Tehnică, Bucureşti.

KUMAR, J., A., V., PATHAN, S., K., BHANDERI, R., J. (2007) Spatio-temporal analysis for monitoring urban growth - a case study of Indore city, J. Indian Soc. Remote Sensing, 35, 1 , pp. $11-20$

LATA, K., M., RAO, C., H., S., PRASAD, V., K., BADARIANTH, K., V., S., RAHGAVASAMY, V. (2001), Measuring urban sprawl: a case study of Hyderabad, GIS Devpt., 5, 12, pp. 26-29. Thesis.

LEȚOS, D., (2010), Modele de dezvoltare durabilă pentru municipiul Piatra Neamț, PhD

LI, X., YEH, A., G., O. (2004), Analyzing spatial restructuring of land use patterns in a fast growing region remote sensing and GIS, Landscape \& Urban Planning, 69, pp. 335-354.

NARISRA, L., DIJST, M., SCHWANEN, T. (2007), A theoretical framework and methodology for characterising national urban systems on the basis of flows of people: empirical evidence for France and Germany, Urban Studies, 44, 11, pp. 2123-2145.

NEMEŞ, V., (2011), The Favorability of Relief For Territorial Expansion of Marghita City, Analele Univeristății din Oradea, Geografie, XXI, 1, pp. 127-133.

PETREA, R., (1998), Dimensiunea geomorfologică în dezvoltarea şi estetica urbană a oraşelor mici din Dealurile de Vest (sectorul dintre Barcău şi Crişul Negru), Ed. Universității din Oradea, Oradea.

SUDHIRA, H., S., RAMACHANDRA, T., V., JAGDISH, K., S. (2004), Urban sprawl: metrics, dynamics and modelling using GIS, Intl. J. Appl. Earth Observation \& Geoinfo, 5, pp. 29-39.

WEBBER, M., J. (1979), Information Theory and Urban Spatial Structure, London, 
Croom Helm.

WILSON, A., G. (2008), Boltzmann, Lotka and Volterra and Spatial Structural Evolution: An Integrated Methodology for Some Dynamical Systems, Journal of the Royal Society, Interface, 5, pp. 865-871.

WILSON, A., G. (2010), Entropy in Urban and Regional Modelling: Retrospect and Prospect, Geographical Analysis.

YEH, A., G., O., LI, X. (2001), Measurement and monitoring of urban sprawl in a rapidly growing region using entropy, Photogrammetric Engg. \& Remote Sensing, 67, 1, pp. 83-90.

(2007), Planul de Dezvoltare Județean - Bihor.

(2009), Fişa Localității, Direcția Județeană de Statistică, Bihor.

(2009), Institutul Național de Statistică, Indicatori din baza de date TEMPO-Online [Online] la https://statistici.insse.ro/shop/.

(2009), Planul Integrat de Dezvoltare Urbană Marghita.

(2009), Planul Urbanistic General Marghita.

Initial submission: 10.05.2012

Revised submission: 08.10.2012

Final acceptance: 30.11 .2012

Correspondence: University of Oradea, Faculty of Geography, Tourism and Sport,

Department of Geography, Tourism and Territorial Planning,

5, Armatei Române Street, Oradea, Romania

E-mail: nemes_vali@yahoo.com 